\title{
DIRECTIONS TO CONTRIBUTORS
}

\section{NOTE}

Full Directions to Contributors, of which this is a summary, appear in the first (February) issue of each volume.

\section{GENERAL}

The Journal of Dairy Research publishes reports on all aspects of dairy science from any country. Material for publication should be sent to the Editor: Dr B. A. Rolls, Institute of Food Research, Earley Gate, Whiteknights Road, Reading RG6 2EF, UK. Receipt of all material will be acknowledged. Submission of a paper will be taken to imply that it reports original unpublished work, that it is not under consideration elsewhere, and that if accepted by the Journal it will not be published elsewhere in any language without the consent of the Editors. Authors of accepted articles will be asked to assign their copyright, under certain conditions, to the Journal.

\section{FORM OF PAPERS}

Papers should be written in English using the spelling of the Concise Oxford Dictionary and should as far as possible be comprehensible to the non-specialist reader. They should be concise, but without omitting necessary material, and contain sufficient detail to allow repetition of the work.

Papers should be typed with wide margins on one side of A4 or quarto paper, double spaced throughout, including References, Figure legends and Table headings and footnotes. Submit a top copy and two good copies packed flat. A single copy will be accepted from outside Europe.

Authors should consult a recent issue of the Journal of Dairy Research to familiarize themselves with Journal conventions and layout. Attention to these and other details will speed publication.

\section{LAYOUT OF PAPERS}

The paper should generally be divided as follows. (a) Cover sheet with the title of the article, names of the authors each with one forename, together with their affiliations, a shortened version of the title suitable as a heading, and the name and address for correspondence. (b) A brief Summary, should encapsulate the whole paper, showing clearly the new knowledge acquired. (c) The introduction, without heading, should not contain a full literature review, but should indicate why the subject of enquiry is interesting or important, and why the authors have chosen the approach described. (d) The Experimental or Materials and Methods section should contain adequate descriptions of procedures or appropriate references; sources of all materials (including address, with post code) and sources or strains of animals, microorganisms and so on should be indicated. (e) Resulls should be as concise as possible, without repetition or inclusion of irrelevant material. Tables and illustrations should be used efficiently. ( $f)$ The Discussion should not repeat the results but discuss their significance. Acknowledgements are given in a separate paragraph without heading. It is the responsibility of the authors to ensure that individuals or organizations acknowledged as providing materials or otherwise are willing to be identified. (g) References. Note. For some types of paper, other divisions may be preferable.

\section{REFERENCES}

References should be given in the text as Brown \& Jones (1987) or (Schmidt, 1985; Nakamura et al. 1989); the first author with et al. is used for papers with three or more authors. Where necessary, papers are distinguished as Lenoir (1988a), (Litov et al. 1990a,b). When several references appear together in the text, cite them in chronological order, and alphabetically within years. The Reference list at the end of the paper, which should begin on a fresh page, is given in strict alphabetical order. Authors should refer to a recent issue for the format of references.

\section{TABLES}

Tables should be numbered and carry headings enabling them to be understood without reference to the text. Each Table should be typed on a separate sheet, but their approximate position in the text should be indicated. Symbols for footnotes should be in the order: $\uparrow, \ddagger, \S, \|, \uparrow$, $\dagger \dagger$, etc. The use of ${ }^{*},^{* *}$, etc, should be limited to indicating levels of significance.

\section{ILLUSTRATIONS}

Line drawings and photographs, which must be originals, should be numbered as Figures in Arabic numerals. Drawings should each be on a separate sheet, not larger overall than those on which the paper is typed, and packed flat. Curves or lines should not extend beyond the experimental points, which should be indicated, symbols used being, in order: $O, \odot, \Delta, \Delta, \square, \square, \times,+$. Final lettering is done at the Press, so there must be no letters or numerals on the drawing or photograph itself. Their positions should be indicated either on a copy of the Figure, or on a translucent flyleaf firmly attached to the Figure. Each Figure should be provided with a legend such that with the Figure it is comprehensible without reference to the text. Figure legends should be typed on a separate sheet or sheets.

Photographs should be glossy black and white prints accompanied by a legend as above. Scale bars on the photograph should be used, not magnifications in the legend. Only one copy of each illustration is required, but authors should ensure that photocopies provided with the other copies of the paper are of adequate quality to allow referees to judge their value.

\section{STATISTICAL TREATMENT}

Individual results should not normally be given. The methods of statistical analysis should be clearly described; a suitable reference is adequate. Authors should make it clear whether they are quoting (e.g.) SD or SE. Any statement that two groups of values are different should be supported by the level of significance involved, as a single or range of $P$ value : $(P=0.008)$ or $(P<0.01)$. Differences should not be claimed or implied if $P>0.05$.

\section{ETHICS OF EXPERIMENTS}

Authors are expected to adhere to the relevant codes covering human subjects and the use of animals.

\section{PROOFS}

Authors will be advised when to expect proofs, which should be returned without delay to Mrs B. Gillian Day, Institute of Food Research, Earley Gate, Whiteknights Road, Reading RG6 2EF, UK. Proofs are sent for the correction of any printer's or editorial errors, not for addition of new material or revision of the text. Excessive alteration may have to be disallowed or made at the authors' expense, and may delay publication. Order forms for offprints are sent with proofs and should be returned directly to The University Press, Cambridge. 
Continued from back cover

Important differences between the generation times of Listeria monocytogenes and List. innocua in two Listeria enrichment broths

F. MACDONALD and A. D. SUTHERLAND

$433-436$

Measurement of proteolysis in cheese : relationship between phosphotungstic acidsoluble $\mathrm{N}$ fraction by Kjeldahl and 2,4,6-trinitrobenzenesulphonic acid-reactive groups in water-soluble $\mathrm{N}$

Y. BOUTON and R. GRAPPIN 


\section{JOURNAL OF DAIRY RESEARCH}

\section{Volume 6r Number 3 August 1994}

\section{CONTENTS}

\section{Original articles}

Pages

Effects on milk yield, somatic cell count and milk conductivity of short-term nonmilking of lactating quarters of cows

J. HAMMAN and P. GYODI

Continuously elevated concentrations of oxytocin during milking are necessary for complete milk removal in dairy cows

R. M. BRUCKMAIER, D. SCHAMS and J. W. BLUM

High affinity $\left(\mathrm{Na}^{+}+\mathrm{Cl}^{-}\right)$-dependent taurine transport by lactating mammary tissue D. B. SHENNAN and $\mathrm{S}$. A. MCNEILLIE

Intramammary pressure and luteal oxytocin after PGF $2 \alpha$ administration in cycling and early pregnant ewes

P.-G. MARNET and J. LABUSSIÈRE

Optimizing clarified whey ultrafiltration: influence of $\mathrm{pH}$

G. DAUTIN, J.-P. LABBE, A. QUEMERAIS, F. MICHEL and U. MERIN

Characterization of the oligopeptides of Parmigiano-Reggiano cheese soluble in $120 \mathrm{~g}$ trichloroacetic acid/1

F. ADDEO, L. CHIANESE, R. SACCHI, S. S. MUSSO, P. FERRANTI and A. MALORNI

Effect of heat treatments on the incorporation of milk serum proteins into the fat globule membrane of homogenized milk

S. K. SHARMA and D. G. DALGLEISH

Detection of powerful odorants in heated milk by use of extract dilution sniffing analysis

L. MOIO, P. ETIEVANT, D. LANGLOIS, J. DEKIMPE and F. ADDEO

Detection of proteolysis in raw milk stored at low temperature by an inhibition

ELISA

C. PICARD, I. PLARD, D. RONGDAUX-GAIDA and J.-C. COLLIN

Simple empirical and fundamental methods to determine objectively the

stretchability of Mozzarella cheese

C. APOSTOLOPOULOS

\section{Short communications}

Evaluation of the inclusion of estimators of body composition in models for the prediction of milk production by dairy cows

A. J. ROOK, M. J. GIBB, W. E. IVINGS, K. ASTON and J. D. SUTTON

Thermal sensitivity of mares' milk proteins

F. BONOMI, S. IAMETTI, E. PAGLIARINI and G. SOLAROLI

Inorganic constituents of milk. V. Ion activity product for calcium phosphate in diffusates prepared from goats' milk

C. HOLT, I. H. L. ORMROD and P. C. THOMAS

Effect of trypsin on bovine lactoferrin and interaction between the fragments under different conditions

L. MATA, H. CASTILLO, L. SÁNCHEZ, P. PUYOL and M. CALVO

Continued inside back cover

(C) Proprietors of Journal of Dairy Research 1994

Printed in Great Britain by the University Press, Cambridge 